\title{
SUPRASEGMENTAL FEATURES OF CI CHILDREN VIA CLASSIFICATION OF PRE-LINGUISTIC UTTERANCES: TWO LONGITUDINAL CASE STUDIES
}

\author{
Paraskevas Binos $^{1}$, Areti Okalidou ${ }^{1}$, Antonios Botinis², Georgios Kiriafinis ${ }^{3}$, Victor Vital ${ }^{3}$ \\ ${ }^{1}$ Department of Educational \& Social Policy, University of Macedonia, Egnatias 156, 54006, Thessaloniki, Greece \\ ${ }^{2}$ Department of Linguistics, University of Athens, Athens 15784, Greece \\ ${ }^{3}$ Academic ENT Department of Medicine, Aristotle University of Thessaloniki, AHEPA Hospital, 54006, Greece
}

Corresponding author: Paraskevas Binos, Department of Educational \& Social Policy, University of Macedonia, Egnatias 156, 54006, Thessaloniki, Greece, Phone: +306934223402, e-mail: pariss61@hotmail.com

Source of support: This research has been co-financed by the European Union (European Social Fund - ESF) and Greek national funds through the Operational Program "Education and Lifelong Learning" of the National Strategic Reference Framework (NSRF) - Research Funding Program: Heracleitus II. Investing in knowledge society through the European Social Fund.

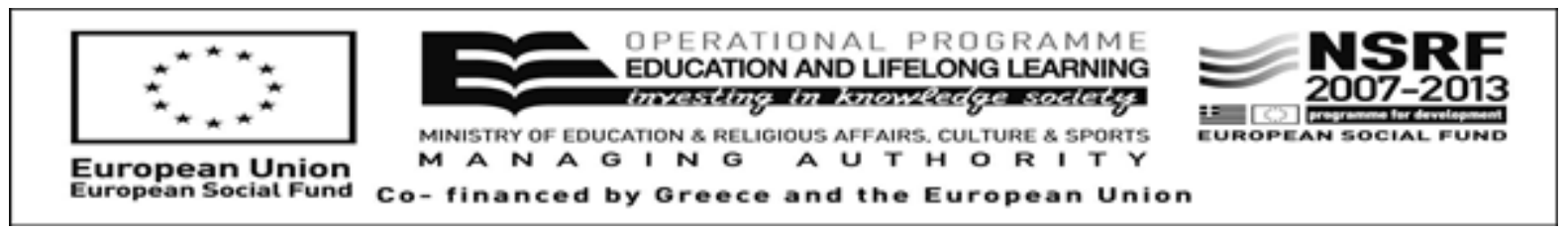

Abstract

Background: The speech prosody of young children who have CIs has not been the subject of detailed investigation. This case study is a longitudinal investigation of the vocalizations of two young children with CIs. The aims were to examine the suprasegmental characteristics of the prelinguistic utterances of these CI children and to develop a method for deriving phonoprosodic classifications using acoustical and auditory analyses.

Material and Method: Spontaneous productions by two congenitally hearing-impaired Greek children fitted with a Nucleus-24 multichannel CI (ages 1: 10 and 2: 7; post-implant ages 0: 0 and 0: 6) were sampled for 6 months and, following transcription, classification of protophones was made. The analysis aimed to detect the frequency of occurrence of different protophone types in the infants' utterances and to examine utterance duration and pitch contour via spectrography. Utterance characteristics were analyzed in relation to a) child's age and b) post-implant age.

Results: At post-implant age of 6 months, the younger and earlier implanted child showed more prelinguistic vocalizations and more complex structures than the older, later fitted child. The older, later CI recipient produced CV vocalizations at the beginning of implantation and gained a facility for frequent CV productions after 4 months of $\mathrm{CI}$ use.

Conclusions: The findings are in agreement with other studies which observe that later CI recipients produce CV combinations at earlier phases of the prelexical period until the necessary auditory input is provided by CIs. Protophone vocalizations serve as a comparative parameter of speech production level in pre-lingual speech.

Key words: cochlear implants $\bullet$ infant vocalizations post-implant $\bullet$ speech production $\bullet$ prelingual deafness $\bullet$ prosodic features

ELEMENTOS PROSÓDICOS EN LAS VOCALIZACIONES DE NIÑOS IMPLANTADOS GRECOPARLANTES ANTES DE LA FORMACIÓN DEL HABLA

\section{Resumen}

Introducción: Las propiedades del balbuceo y los rasgos de la prosodia del habla de los niños pequeños con implantes cocleares no han sido estudiados detalladamente. Este trabajo presenta los resultados de la observación a largo plazo de los modelos suprasegmentales en las vocalizaciones de dos niños pequeños a los que se les había colocado implantes cocleares. El objetivo del estudio era: a) estudiar los rasgos - la duración y la altura de los sonidos emitidos antes de la formación del habla; b) 
elaborar un nuevo modelo de clasificación de los sonidos primarios en los niños implantados; y c) seguir las tendencias de desarrollo de la vocalización de bebés desde el punto de vista de la estructura sonora y prosódica.

Material y método: El material lo constituían dos niños griegos de 10 y 7 años de edad con déficit auditivo profundo que utilizaban sistemas de implantes cocleares (implantes multicanales Nucleus-24). Durante el estudio, por un periodo de 6 meses, se grabaron las vocalizaciones espontáneas de los niños en intervalos mensuales. El análisis de la duración y la altura de los sonidos emitidos por los niños se realizó en base a las grabaciones espectográficas utilizando en programa Praat. Los sonidos primarios registrados en las vocalizaciones emitidas por los niños fueron sometidos a un análisis cualitativo y divididos en dos tipos conforme al modelo infrafonológico de Oller. En las tablas se presentó la frecuencia de los tipos de sonidos primarios. Se analizaron los rasgos característicos de los sonidos en lo que se refiere a a) la edad del niño, b) el tiempo transcurrido desde la colocación del implante coclear.

Resultados: La estructura de los sonidos primarios dependía de la edad que tenía el niño cuando se le colocó el implante coclear. Las vocalizaciones del niño al que se le colocó antes el implante coclear (a una edad más temprana) eran más complejas. En ambos niños se observó la unión de las consonantes y las vocales 6 meses después de la colocación del implante.

Conclusión: Los resultados actuales sugieren que el paso lineal de estructuras del habla inmaduras a maduras en los niños con implantes cocleares se produce en una etapa temprana de desarrollo de esta capacidad. Parece que el análisis de los sonidos primarios es una corriente de investigación razonable, ya que puede servir para observar la aparición de trastornos adicionales o problemas de comunicación en los niños pequeños con implantes cocleares.

\section{ПРОСОДИЧЕСКИЕ ЭЛЕМЕНТЫ В ВОКАЛИЗАЦИЯХ ИМПЛАНТИРОВАННЫХ ГРЕКОЯЗЫЧНЫХ ДЕТЕЙ ПЕРЕД РАЗВИТИЕМ РЕЧИ}

\section{Изложение}

Введение: Свойство агуканья и признаки прозодии речи у маленьких детей, пользующихся улитковыми имплантатами еще тщательно не исследованы. Эта работа представляет результаты длительного наблюдения супрасегментальных образцов в вокализациях двоих маленьких детей, которым вживлены улитковые имплантаты. Цель исследования: а) исследование свойств- времени продолжания и высоты звуков, издаваемых перед развитием речи, б) разработка новой модели классификации примарных звуков у имплантированных детей, в) обзор трендов развития вокализации у грудных детей по отношению к звуко-просодической структуре.

Материал и метод: Материал - двое греческих детей в возрасте 10 и 7 лет, с глубокой потерей слуха, пользующихся системами улитковых аппаратов (многоканальные имплантаты Nucleus-24). Во время исследования на протяжении 6 месяцев записаны спонтанные вокализации детей в ежемесячных интервалах. Анализ времени продолжения и высоты звуков, издаваемых детьми, произведен на основании спектрографических записей с использованием программы Praat. Примарные звуки, зарегистрированные в издаваемых детьми вокализациях, подвергнуты качественному анализу и разделены на два типа согласно инфра-фонологическому методу по Оллеру. Частота наличия типов примарных звуков представлена в таблицах. Характеристические свойства звуков были анализированы по отношению к а) возрасту ребенка, б) времени после вживления улиткового имплантата.

Результаты: Структура примарных звуков зависела от возраста ребенка в момент вживления улиткового имплантата - у ребенка, у которого улитковый имплантат был ранее вживлен (в младшем возрасте) вокализации были более сложными. У обоих детей наличие соединений согласных и гласных наблюдалось через 6 месяцев после вживления имплантата.

Итог: Актуальные результаты предполагают наличие у детей, пользующихся системой линейного улиткового имплантата переходы от незрелых к зрелым структурам речи на раннем этапе развития этого умения. По всей вероятности анализ примарных звуков - это правильное направление исследований, потому что он может служить в качестве наблюдения наличия дополнительных нарушений или коммуникационных проблем у маленьких детей, пользующихся улитковыми имплантатами.

\section{ELEMENTY PROZODYCZNE W WOKALIZACJACH IMPLANTOWANYCH DZIECI GRECKOJĘZYCZNYCH PRZED WYKSZTAŁCENIEM MOWY}

\section{Streszczenie}

Wprowadzenie: Właściwości gaworzenia i cechy prozodii mowy u małych dzieci korzystających z implantów ślimakowych nie są dokładnie zbadane. Niniejsza praca prezentuje wyniki długotrwałej obserwacji suprasegmentalnych wzorców w wokalizacjach 
dwojga małych dzieci, którym wszczepiono implanty ślimakowe. Celem badania było: a) zbadanie cech - czasu trwania i wysokości dźwięków wydawanych przed wykształceniem mowy; b) opracowana nowego modelu klasyfikacji głoski prymarne u dzieci implantowanych; i c) prześledzenie trendów rozwoju wokalizacji niemowląt pod względem struktury głoskowo - prozodycznej.

Materiał i metoda: Materiał stanowiło dwoje greckich dzieci w wieku 10 i 7 lat, z głębokim ubytkiem słuchu korzystających z systemów implantów ślimakowych (implanty wielokanałowe Nucleus-24). Podczas badania, przez okres 6 miesięcy, nagrywano spontaniczne wokalizacje dzieci w comiesięcznych odstępach. Analiza czasu trwania i wysokości dźwięków wydawanych przez dzieci została dokonana na podstawie nagrań spektrograficznych z zastosowaniem programu Praat. Głoski prymarne zarejestrowane w wydawanych przez dzieci wokalizacjach zostały poddane analizie jakościowej i podzielone na dwa typy zgodnie z podejściem infrafonologicznym wg. Ollera. Częstotliwość występowania typów głosek prymarnych została przedstawiona w tabelach. Cechy charakterystyczne dźwięków była analizowane w odniesieniu do a) wieku dziecka, b) czasu od wszczepienia implantu ślimakowego.

Wyniki: Struktura głosek prymarnych była uzależniona od wieku dziecka w momencie wszczepienia implantu ślimakowego - u dziecka u którego implant ślimakowy został wszczepiony wcześniej (w młodszym wieku) wokalizacje były bardziej złożone. U obojga dzieci występowanie połączeń spółgłosek i samogłosek zaobserwowano 6 miesięcy po wszczepieniu implantu.

Wniosek: Aktualne wyniki sugerują istnienie u dzieci korzystających z systemu implantu ślimakowego liniowego przejścia od niedojrzałych do dojrzałych struktur mowy na wczesnym etapie rozwoju tej umiejętności. Wydaje się, że analiza głosek prymarnych jest słusznym kierunkiem badań, gdyż może służyć jako obserwacja w kierunku występowania dodatkowych zaburzeń lub problemów komunikacyjnych u małych dzieci korzystających z implantów ślimakowych.

\section{Background}

Following Chomsky's "universal grammar" theory, a scientific approach about how all natural human languages share common properties, Davis et al. [1] suggested that not only adult patterns but even the babbling patterns of babies are common between languages. Oller [2] described this viewpoint as an "international consensus". Subsequently, Vihman [3] found that, across languages, infant vocalizations contain syllable types common to both the last stages of babbling and early meaningful speech. This claim disagrees with older concepts $[4,5]$ of a non-gradual, discontinuous transition between babbling and early word patterns; it has also opened up new diagnostic and rehabilitative prospects for human communication science which focus on infant speech instead of on "shoehorning" the phenomena of adult language [6].

Based on this current theoretical framework, the study of the babbling period is of great importance since it delineates early speech development; moreover, it establishes a possible prognosis for subsequent speech and language development. As Oller et al. [7] stated, "delayed onset of canonical babbling can predict delay in the onset of speech production" (p.223). The crucial stage of canonical babbling as a transitional step to early language was described also by Stoel-Gammon [8] while outlining the stages in the development of pre-speech vocalizations. Ertmer et al. [9] found that normal children reach this babbling stage, called canonical babbling, at 6-7 months of age.

Prosody refers to three types of language phenomena: phrasal stress, boundary cues, and meter [10]. This study focuses on suprasegmental aspects of phonological development, aiming to provide an independent description of prosodic structure by utilizing principles of prosodic phonology [11]. In contrast, most other studies in children with cochlear implants (CIs) examined segmental characteristics of their speech $[12,13]$. As Hargrove [14] mentions, prosody includes not only rhythm, stress, intonation, and tempo but also other linguistically relevant variables connected to phonetics, such as features of pitch, duration, pause, and intensity [15]. These features are named 'suprasegmentals' due to their characteristic of extending beyond the limits of phonetic segments.

Various studies have been conducted on infant prosody [16-18] and the paralinguistic information it conveys $[19,20]$. However, Nathani et al. [21] pointed out that there is a scarcity of studies on the prelinguistic vocal development of children with hearing impairment. Among them, very few have examined the spontaneous speech and the suprasegmental features of congenitally hearing-impaired children wearing cochlear implants [22-24]. The scarcity of studies is even more pronounced for languages other than English. In particular, for Greek-speaking populations no such studies have yet been conducted.

From a theoretical and clinical point of view, study of the outcomes of cochlear implantation on early vocalization patterns is a big challenge. During the process of analyzing infant speech, various obstacles arise which decrease reliability across observers. These include variability in transcribing the place and manner of articulation of consonants as well as specifying vowel identity. As far as we can see, the search for a model linking the patterns of infant speech with adult speech is long under way. However, for children with hearing impairment one needs to explore how linear the transition from protophonic sounds of prelexical speech to normal adult speech is, considering the innate as well as the language-varying aspects of babbling.

In recent years, many scientists have pinpointed several methodological pitfalls in analysing infant speech which need to be overcome in future work. Oller et al. [25] posed basic concerns regarding the selection criteria of early pronunciation for analysis, highlighted the limitations of using IPA to transcribe infant speech, and suggested alternative ways of analysis via an infraphonological framework [26]. Nathani et al. [6] introduced further methodological changes to the analysis of infant speech. These were: a) the separation of useful protophones from what we 
Table 1. Characteristics of the two implanted children involved in this study.

\begin{tabular}{ccccccc}
\hline Child & $\begin{array}{c}\text { Chronological } \\
\text { age (CA) }\end{array}$ & $\begin{array}{c}\text { Age at receiving } \\
\text { Cls }\end{array}$ & $\begin{array}{c}\text { Post-implant age } \\
\text { (PIA) }\end{array}$ & $\begin{array}{c}\text { Reason } \\
\text { for Cl }\end{array}$ & $\begin{array}{c}\text { Onset of hearing } \\
\text { loss }\end{array}$ & $\begin{array}{c}\text { Additional } \\
\text { disability }\end{array}$ \\
\hline GR & $1: 10$ & $1: 4$ & $0: 6$ & Profound HL & Congenital & No \\
\hline SE & $2: 1$ & $2: 1$ & $0: 0$ & Profound HL & Congenital & No \\
\hline
\end{tabular}

call "vegetative" sounds; b) a developmental definition of an utterance and its boundaries; and c) the use of timelocked digital recording that overcomes the limitations of analog measurements. Trying to achieve higher reliability, Koopmans-van Beinum et al. [27,28] adopted a different way to describe precanonical sounds based on coordination of movements of the phonatory and articulatory systems. They argued that coordination of speech movements is a necessary milestone before achieving normal speech production. Indeed, Schauwers et al. [29] provide evidence that the onset of babbling is not only a precursor to speech but is also a speech motor control milestone.

Speech perception for pre-, peri-, and post-lingually deaf children with CIs or hearing impairment has being studied in great detail and the benefits of cochlear implantation have already been described [9,30-32]. The bulk of studies have focused on comparisons between children with CIs and children with hearing aids, with respect to both their sound perception and production abilities [30,33-35]. Baudonck and colleagues [33] have explored how consonants are produced and how consonant production depends on the age of implantation. With respect to production abilities, Löhle et al. [34] have found better performance for young CI children (2-4 years old). In interactions with mothers or therapists, differences were found in the imitation of prosodic features of speech in F0, intonation, rhythm, stress, and vowel duration, and Löhle et al. concluded that the sooner children are fitted with cochlear implants the better their performance.

There is some evidence that speech production skills may sometimes precede perception skills. Kishon-Rabin and colleagues [36] found that, based on comparisons of phonological contrasts, their Hebrew CI group (age 2.5-10 years) developed production skills before perception. It therefore appears that speech production plays a crucial role in communication development. However, more research is needed to unravel the development of production skills in early implanted children. Previous research on speech production has placed little emphasis on the suprasegmental features of young children's speech with CIs [13,37-39]; instead, the focus has been on post-lingually deafened adults with experience in producing intelligible speech $[40,41]$. Segmental analyses $[9,13,42-44]$ or methodologies based on elicited answers $[24,38]$ have not formally analyzed the suprasegmental features of speech in CI children via a classification of protophonic types.

The current longitudinal case studies are the first part of a larger scale study. It reports on the spontaneous productions of two young children fitted with cochlear implants during parent-child interactions, focusing on the suprasegmental features of these productions. The goal of this work is to develop a methodology for protophone classification avoiding elicited techniques or participation by the mother, which have been commonly used previously $[45,46]$. The present study is influenced by the methodological approach of Karousou et al. [47]. That study was based on three typically developing cases: two Greek-speaking children and one Spanish-speaking child. The authors attempted to trace developmental changes in the phonoprosodic shape of prelinguistic vocalizations in order to determine whether the transition to language is continuous or not. Karousou et al. [47] present a quantified classification of prelinguistic vocalizations, similar to the present study, and measurements of the prosodic features of intonation and rhythm. A new methodological approach is tested here, expanding that of Karousou et al. in two ways. First, we evaluate the vocalizations of a different type of population, that is, very young CI recipients, using a new classification scheme. The second difference is proposing a different method of data analysis, namely the acoustic analysis of prosodic parameters. Karousou et al. [47] measured intonation and rhythm using perceptual criteria whereas this study adopts acoustic measures of duration and pitch. The present study is the first one that aims to investigate the duration and pitch parameters of Greek protophone types in CI children. According to Jusczyk [48], variation of pitch values is a critical achievement in early language development.

\section{Material and Method}

\section{Subjects}

Two longitudinal case studies are presented. The participants were two congenitally hearing-impaired girls, GR (chronological age 1:10; post-implantation age 0:6-0:10) and SE (chronological age 2:7; post-implantation age 0:0-0:6) of Greek-speaking hearing parents. Their demographic characteristics with respect to hearing loss are depicted in Table 1. These children were selected because they were implanted early, during the second year of life, with a Cochlear Nucleus-24.

Participants had no other disabilities and had unknown deafness etiology. The families of the participants were characterized as typical median socio-economic class. They received detailed instructions and frequent face-to-face training during the process. Before the study both families provided written consent for their child's participation according to the ethical standards set for the confidential and anonymous treatment of participants' data. Prior to implantation the children had an average unaided hearing loss of more than $90 \mathrm{~dB}$ in the better ear.

\section{Data collection}

Vocalizations were recorded by using a Sony PCM-D50 portable linear digital recorder using a sampling rate of 
Table 2. Babbling stages of typically developing children.

\begin{tabular}{cc}
\hline $0-2$ months & Phonation stage \\
\hline $2-4$ months & Cooing/Gooing stage \\
\hline $4-7$ months & Expansion stage \\
\hline $7-10$ months & Canonical stage \\
\hline $10-12$ months & Variegated stage \\
\hline
\end{tabular}

44.1 kHz and 16-bit precision. The machine contains two built-in electret condenser microphones, offering a selection of two operating positions, hence covering a wide sound range with a natural sounding image. Audio recordings of approximately 40-60 minutes per session aimed to capture spontaneous parent-child interactions and were carried out in the children's homes over a span of 6 months during the first year post-implant. A record of protophones was created for each recorded session. SE was recorded from the first month after implantation and GR was first recorded at 6 months of implant use.

\section{Vegetative sounds and fixed signals: separation from protophones}

Recordings were made each month for 6 months. Subsequent editing was done to remove vegetative data and vocalizations masked by external noise or sounds. Specifically, cries, burping, gulping, laughing, hiccoughing, sneezes, coughs, sudden loud sounds, and long pauses were excluded. These exclusion criteria yielded four useful recordings for each subject for the span of 6 months. The final corpus used for analysis was approximately 15 minutes long per month and it contained all of the children's prelinguistic vocalizations uttered during a given recording.

This study is focused on protophones because they are produced in situations that do not involve obvious elicitation by an external factor. This is a methodological step that other studies have made [6] for acoustical analysis. Vocalizations were analyzed by one experienced researcher in terms of Oller's infraphonological approach and Karousou et al.s [47] classification model. The classification pattern contained isolated productions of vowels but also all the prelinguistic vocalizations involving combinations of consonants and vowels. For each utterance, two suprasegmental features were analyzed, pitch and duration. Suprasegmental analyses were based on inspection of spectrographic records using Praat analysis software for Windows (4.110).

\section{Method of data analysis}

Babbling is defined as "the occurrence of multiple articulatory movements in one breath unit combined with continuous or interrupted phonation" [49]. All utterances that were consistent with the above definition were analyzed as babbling. Segmental categorization and classification of the utterance structure was based on Oller's infraphonological approach [2] which can adequately code complex infant vocalizations (Table 2). Following that line of work, Karousou's et al. [47] classification model was adopted and slightly modified to fit the vocalizations of the current sample of implanted children. This classification scheme presents a gradual transition from prelingual vocalizations to transcription of adult-like speech. Karousou et al. [47] based their classification on Oller's approach but used both perceptual and acoustical analyses to quantify the schemes of segments and the prosodic properties of intonation and rhythm of the utterances.

In these two case studies, the characteristics of protophone types were classified into five categories, based on their segmental structure. This qualitative template depicted speech development according to chronological and post-implant age over a span of 6 months. In addition, suprasegmental measurements for all protophone types in the classification scheme were made.

The protophone types were classified into five categories listed below:

1. Isolated vowels $(\mathrm{V})$. These precanonical vocalizations are important for language development. The isolated vowels were counted as full vowel elements. Karousou et al. [47] included them in their analysis as well.

2. Monosyllables (CV-CCV-VC). At this point only canonical syllables were counted, as Oller defined them. Each canonical syllable contained one full vowel-like element as well as one consonant-like with a rapid transition between the two.

3. Disyllables (CVCV-VCV-CVCVC), as canonical syllables with more complex structure.

4. Trisyllables (VCVCV-CVCVCV).

5. Polysyllables (reduplicated/variegated babbling) with more than three syllables.

In addition to the canonical syllabic form that Oller [26] describes, there are more complex vocalizations. As Oller [26] states, some languages bring additional types of the canonical syllables. Thus, it is possible to have a CCV, VC, or VCV type as variable types of the canonical; consequently these types are included in the current study. The importance of the CV type is highlighted by the fact that it is the only universal syllable and a milestone in the language developmental stages [50].

\section{Acoustical analysis procedures}

The method combined the acoustic analyses procedure with the basic principles of infraphonology analysis which sets rules for the kinds of segments to be excised from the speech stream and measured. Each protophonic production was defined and subsequently analyzed independently by using spectrographic analysis via Praat.

Duration and pitch contour of utterances were analyzed by inspection of spectrographic records. Pitch measurements included mean, minimum, and maximum pitch. To measure the degree of pitch change within an utterance, the minimum pitch value was subtracted from the maximum pitch value. This difference between max and min pitch served as an indication of prosodic fluctuation during babbling. The pitch floor was set to $75 \mathrm{~Hz}$ and the pitch ceiling to $800 \mathrm{~Hz}$ based on pilot studies prior to the main procedure. Duration of utterances was determined by inspecting the 
Table 3. Quantitative vocal analysis of SE (number of protophones) over a span of 6 months.

\begin{tabular}{|c|c|c|c|c|c|c|c|c|c|c|c|c|c|}
\hline PIA & CA & $\mathbf{v}$ & cv & cvv & vcv & cvc & ccv & cvcr & cvcve & vevev & cvcvv & $\begin{array}{l}\text { Redupli- } \\
\text { cated }\end{array}$ & $\begin{array}{l}\text { Varie- } \\
\text { gated }\end{array}$ \\
\hline $0 ; 0$ & $2 ; 1$ & & 2 & & 1 & & & & & & & 1 & \\
\hline $0 ; 1$ & $2 ; 2$ & & 4 & & & 1 & & & & & & & \\
\hline $0 ; 4$ & $2 ; 5$ & & & & & & & & 2 & & & & \\
\hline $0 ; 6$ & $2 ; 7$ & & 1 & 2 & & 1 & 4 & 1 & & 1 & 2 & 1 & 2 \\
\hline
\end{tabular}

Table 4. Quantitative vocal analysis of GR (number of protophones) over a span of 6 months.

\begin{tabular}{|c|c|c|c|c|c|c|c|c|c|c|c|c|c|c|c|}
\hline PIA & CA & $\mathbf{v}$ & cv & vc & cvv & vcv & cvc & cvev & vvcrcv & crvcrv & vcrvev & cvcrv & cvvcv & $\begin{array}{l}\text { Redupli- } \\
\text { cated }\end{array}$ & $\begin{array}{l}\text { Varie- } \\
\text { gated }\end{array}$ \\
\hline $0 ; 6$ & $1 ; 10$ & 22 & 7 & & 12 & & 1 & 31 & & 1 & & 1 & & 5 & 6 \\
\hline $0 ; 7$ & $1 ; 11$ & & 1 & & 2 & & & 11 & & & & & & 2 & \\
\hline $0 ; 9$ & $2 ; 1$ & & & & 1 & 1 & & 7 & & & & & & & \\
\hline $0 ; 11$ & $2 ; 3$ & 2 & 5 & 1 & & 5 & & 21 & 1 & & 1 & & 1 & 1 & 1 \\
\hline
\end{tabular}

spectrogram in relation to the waveform and marking the onsets and offsets of the first and last phoneme of the utterances. The procedure adopted the infraphonological approach principle according to which the durations for the canonical syllable reach an upper limit of about $500 \mathrm{~ms}$. Consonant-vowel boundaries and their reduplications were defined according to formant energy structure. Thus, the onset of an utterance was defined as the visible onset of a consonant structure in the case of $\mathrm{CV}$ onsets, or of the formant structure in the case of VC onsets. Duration measurements were made by visually inspecting the waveform in combination with the spectrogram. Adapting the same methodological steps of duration measurement by Hide et al. [22], CV open forms were defined from the onset of consonant closure to the end of the vowel in the spectrogram. The end of the vowel was determined as the point of the first cycle having markedly decreased amplitude.

One-way repeated measures ANOVAs were performed for each subject, to examine whether mean duration and the absolute value of mean pitch difference (since there is no distinction based on the direction of the contour) change significantly as a function of protophone type. Mean duration and pitch values were calculated for each protophone type.

\section{Results}

GR had lower chronological age (1:10-2:3) and was implanted at a younger age (1:4) than the other older participant, SE (chronological age 2:1-2:7; implantation age $2: 1$ ). Tables 3 and 4 show the overall number of vocalizations over a span of 6 months during the first year postimplant and the frequency of occurrence of each protophonic utterance as a function of chronological age and post-implant age for each of the two participants.

\section{Case SE}

SE increased the number of productions and their quality, producing complex prelinguistic types of VCVCV, CVC,
CVCVV forms, and even producing variegated babbling, at 6 months after implantation (see Table 3). This diversity involved vocalization types with either initial consonants or vowels, since the analyses separate VCVCV and CVC types respectively. The speech of SE contained isolated productions of vowels with large durations, longer than the monosyllables, disyllables, and trisyllables.

\section{Case GR}

GR's tendency to longer and complex protophone types can be observed as early as 6 months post CI (Table 4). The speech of GR contains, at first, vowels with large durations, as can be seen in Figure 1 at 6 months post-implant, while vowel duration decreased across development in complex types. This child also showed a significant decrease in the number of isolated vowel productions across the months of observation, since she produced 22 isolated vowels at 6 months post-implant, versus only two after another 6 months (chronological age 2:3).

The duration and pitch values for each type of protophone are depicted on graphs for both children separately (Figures 1 and 2). According to statistical analyses, pitch and duration parameters can be described in two main parts for each child, as follows.

\section{Pitch measures}

The mean difference between maximum and minimum pitch values for both CI cases and for each protophone type is depicted in Figure 2. One-way repeated measures ANOVA for the five protophone categories revealed no change in mean pitch difference as a function of photophone types for both subjects. Cut-off levels of significance were set at 0.05 for all tests. Specifically, subject SE, despite the absence of statistically significant mean pitch differences $(F=1.57, p=0.34>0.05)$ across protophone types, shows great variability in pitch values across the protophonic types, especially between monosyllable and the di- or 
A
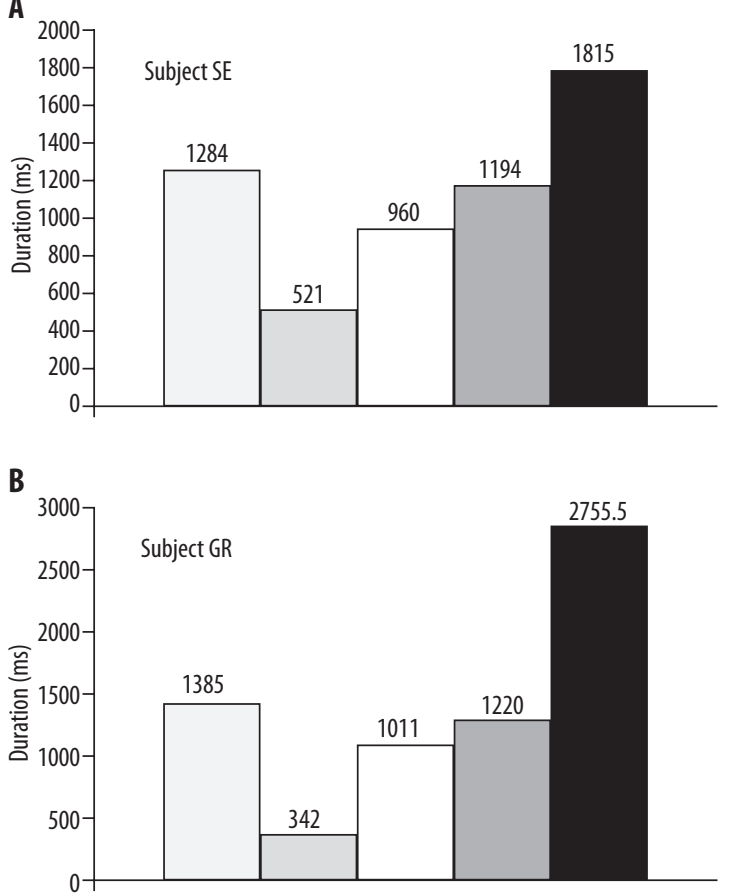

$\square$ V isolated $\square$ Monosyllables(cv-ccv-vc)

$\square$ Disyllables(cvcv-vcv-cvcrc) $\square$ Trisyllables(vcvcv-cvcrcv)

Reduplicated/variegated

Figure 1. Mean duration measurements of protophone types for subject SE (A) and GR (B).
A

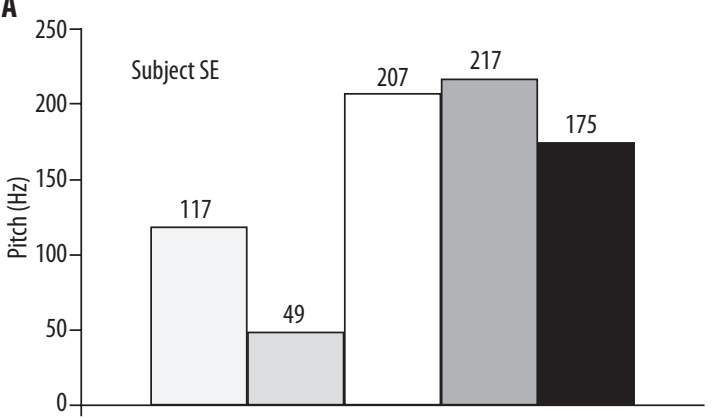

B

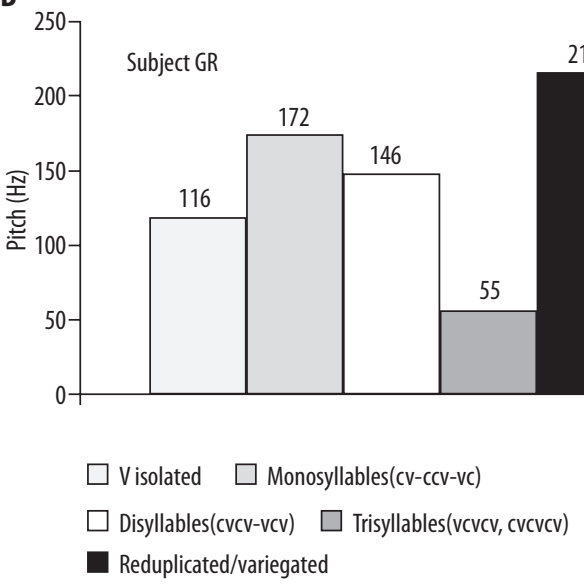

Figure 2. Mean pitch difference measurements of protophone types for SE (A) and GR (B).

Table 5. Comparison of the two cases (SE and GR) at 6 months PIA.

\begin{tabular}{|c|c|c|c|c|c|c|c|c|c|c|c|c|c|}
\hline & $\mathbf{v}$ & cv & cvV & vcv & cve & ccv & cvcr & cveve & vcvev & cvcrv & cvvcrv & $\begin{array}{l}\text { redupli- } \\
\text { cated }\end{array}$ & $\begin{array}{l}\text { varie- } \\
\text { gated }\end{array}$ \\
\hline SE & 1 & 2 & & 1 & 4 & 1 & & 1 & 2 & 1 & & & 2 \\
\hline GR & 22 & 7 & 12 & & 1 & & 31 & & & 1 & 1 & 5 & 6 \\
\hline
\end{tabular}

trisyllable protophones. In addition, there were small, nonsignificant differences between the longer structures. Similar variability in mean pitch value was noted across the protophone types for GR as well, especially among the reduplicated/variegated babbling and the trisyllables. However, the difference between them was not statistically significant $(p=0.31>0.05)$.

\section{Duration measures}

The mean duration for both CI cases and for each protophone type is depicted in Figure 1. One-way ANOVAs show significant differences in mean duration of protophones for SE $[F(4.4)=8.23, p=0.03<0.05]$ as a function of protophone type while there was no significant difference in the mean duration across protophonic types for GR $[F(4.4)=3.06, p=0.15>0.05]$. Both participants show longer durations for the isolated vowel as compared to monosyllables, disyllables, and trisyllables.
Comparison of the two cases at 6 months of post-implant use

A direct comparison of prelinguistic vocalizations for the two cases can be made at 6 months of implant use. Table 5 presents the comparison of these two cases only at their common point of 6 months of implant use. Their performance differs qualitatively and quantitatively at 6 months of post-implant use. It is worth mentioning that GR showed an advanced performance level at 6 months after implant compared to SE. In particular, she produced more protophones than SE and even for complex types (diversity of CV types or reduplicated/variegated babbling), while SE showed a smaller number of productions despite the similar width of variation at 6 months post-implant.

\section{Discussion}

Babbling is defined by Oller et al. [51] as the ability of a child to produce vocal types that share characteristics with mature speech. This case study, as the first part of a 
larger study, was a preliminary analysis that focused on prelexical vocalizations of two very young CI recipients. The study of prosody and the paralinguistic information that it conveys has been studied in depth for both adults and children. On the other hand, the study of suprasegmental features in the speech of children wearing cochlear implants needs further work. The importance of CIs for language development has already been demonstrated by recent studies that mention the benefits of implants for speech development at all levels and for hearing perception improvement [52]. The most important aspect of the current results was that, 6 months after cochlear implantation, the younger recipient showed a different, more complex developmental profile and a better performance level in contrast with the chronologically older recipient.

In sum, we can state two main observations:

1. The younger, early implanted child (GR) showed a larger number and a greater variety of complex patterns at 6 months post-implant (CVV-VVCVCV-CVVCVV) (see Table 5) than the older child. Since both were matched for a post-implant age of 6 months their performances were readily comparable. The result could be attributed merely to individual differences or the age of implantation. On the other hand, the trends which were noted in duration measures for the two subjects indicate that the strategies both children used seemed to be different. As Boons et al. [53] mention, better language performance by CI users can be due to an implantation age under the age of two, as in the current sample, whereas implantation at a much younger age seems unrelated to better language profiles, as observed after 3 years of CI experience. Other possible factors that seem to be tied to the CI user performance in these case studies are oral communication by the parents and monolingualism, both of which formed the basic criteria for this research. Finally, these children did not have any additional disabilities that might have negatively affected their overall performance, another basic exclusion criterion of the current research. Protophone vocalizations serve here as comparative parameter of speech production level in prelingual speech. Based on these findings, more research has to be undertaken to derive robust conclusions.

2. The late $\mathrm{CI}$ recipient, SE, produced CV combinations that corresponded to earlier phases of the prelexical period. These increased with duration of auditory input from the implant.

A contribution of the current research is that it offers a methodology for protophone classification of CI children's vocalizations, by utilizing a combination of acoustical and auditory analyses. To the authors' knowledge, no studies have so far examined the speech production characteristics of prelingual CI children based on acoustical and auditory analyses, leading to a quantified supplement of the classification scheme. The above analysis showed a gradual transition from immature to mature, adult-like vocalizations, but more research needs to be done with a longer time of observation postoperatively and a larger number of participants. The current finding that the late CI recipient produced CV combinations at earlier phases of the prelexical period is in agreement with the recent research of Schauwers et al. [12] who mentioned a similar trend.
A similar study [31] described suprasegmental features of deaf children with CI, tactile aids, or hearing aids, but they used elicited answers rather than spontaneous speech. In a more recent paper of Lenden et al. [24], the authors note, on the one hand, the lack of similar studies focusing on suprasegmental features of CI children; on the other hand, they used children with a mean chronological age of 5 years. Their sample also contained children with 2: 8 years of cochlear implant use, in contrast with the current research. Hide et al. [22] presented an acoustical analysis of suprasegmental aspects of CI users speech, but they focused only on vowel features with respect to pitch change, F0, and duration. They concluded that, already from the stage of pre-lexical speech, CI positively affects performance level. The research of Liwo [52] was also qualitatively different. There was no phonoprosodic classification as her analysis was based on different parameters such as rhythm, melody, and accent.

An obvious limitation of the current study is that only two participants were reported and our observation time was 6 months. The size of the sample therefore precludes broad conclusions about the best age of implantation and about CI's improved language abilities. Nevertheless, Schauwers et al. found a linear correlation between age at implantation and the onset of prelexical babbling [42]. Many factors are responsible for the current limitation. Our sample choice was determined by needing a relatively small chronological age of CI wearing, no other additional disorders or disabilities, and the rejection of bilingual recipients. Subject selection criteria were also set based on the requirements indicated by previous studies: Lenden et al. [24] stated the need for acoustical analyses of various aspects of prosody and for analyzing the speech of children with much less post-implant experience. The observation length adopted by this study, i.e. 6 months, is not uncommon in other longitudinal studies in young children. For example, Hide et al. [22] or Schauwers et al. [49] used the same period of sample observation in their study of prelexical speech of CI children.

The current findings do have some potentially important clinical implications. First of all, protophone classification integrated with acoustical and auditory analyses was used as a comparative parameter of speech production level in pre-lingual speech for children wearing cochlear implants. More research needs to be done to establish this tool as diagnostic; it will form part of a broader study and the present case study lays the foundations. This approach agrees with that of Oller et al. [7] who recommended that the stage of canonical babbling with reduplicated/variegated sequences can serve as a possible predictor of poor speech production. Secondly, the fact that the late recipient produced an earlier stage of babbling CV combinations may indicate that a cochlear implant acts as a trigger, causing a babbling spurt when the necessary auditory input is provided. This suggests that the child was able to produce pre-linguistic vocalizations but there was not the necessary motivation until they received an implant.

\section{Conclusions}

These two separate case studies are part of a larger research program which is underway, using larger samples 
and comparisons. This study used Oller's infraphonological approach to study protophone classifications in the speech of early-implanted children. It presents a new way of integrating acoustical and auditory analyses in the study of CI vocalizations. The current findings suggest that protophonic development is rapid during the first post-implantation year. We suggest that future research uses larger samples, comparisons with typically developing children, broader suprasegmental analyses, and longer longitudinal studies. So far the findings of this study contribute to the existing data of babbling in children wearing CIs at a very young age. Hence, they serve as a basis for future investigation and development of prognostic tools for the communication of young, early-implanted CI children.

\section{Acknowledgments}

The authors warmly thank both families that participated in the research. We also thank the University Hospital of AHEPA, Thessaloniki, and especially the ENT clinic for support. We are grateful to Dr Laura Koenig for her invaluable help and suggestions. This research has been cofinanced by the European Union (European Social Fund) and Greek national funds through the operational program "Education and Lifelong Learning" of the National Strategic Reference Framework (Heracleitus II).

\section{References:}

1. Davis B, MacNeilage P, Matyear C. Acquisition of serial complexity in speech production: A comparison of phonetic and phonological approaches to first word production. Phonetica, 2002; 59: 75-107.

2. Oller DK. Development of vocalizations in infancy. In: Winitz $\mathrm{H}$, editor. Human communication and its disorders: A review. $4^{\text {th }}$ ed. Timonium: York Press, $1995 ; 1-30$.

3. Vihman MM. Individual differences in babbling and early speech. In: Lindblom B, Zetterstrom R (eds.), Precursors of early speech. New York: Stockton Press, 1986; 21-35.

4. Jakobson R. Kindersprache, Aphasie, und allgemeine Lautgesetze. Uppsala: Almqvist and Wiksell; 1941

5. Carroll JB. Language Development. In: Harris CW, American Educational Research Association (eds.), Encyclopedia of educational research; a project of the American Educational Research Association. $3^{\text {rd }}$ ed. New York: Macmillan, 1960; 744-52.

6. Nathani S, Oller DK. Beyond ba-ba and gu-gu: Challenges and strategies in coding infant vocalizations. Behav Res Methods Instrum Comput, 2001; 33(3): 321-30.

7. Oller DK, Eilers R, Neal A, Schwartz H. Precursors to speech in infancy: The prediction of speech and language disorders. J Comm Disord, 1999; 32: 223-45.

8. Stoel-Gammon CS. Role of babbling and phonology in early linguistic development. In: Wetherby AM, Warren SF, Reichle J (eds.), Transitions in prelinguistic communication. Baltimore: Brookes;1998; 7: 87-110.

9. Ertmer D, Mellon J. Beginning to talk at 20 months: Early vocal development in a young cochlear implant recipient. JSLHR, 2001; 44: 192-206.

10. Gerken LA, McGregor KK. An overview of prosody and its role in normal and disordered language. American J SpeechLanguage Pathology, 1998; 7: 38-48.

11. Gerken LA. Prosodic structure in young children's language production. Language, 1996; 72: 683-712.

12. Schauwers K, Gillis S, Govaerts P. The characteristics of prelexical babbling after cochlear implantation between 5 and 20 months of age. Ear Hear, 2008; 29: 627-37.

13. Schauwers K, Taelman H, Gillis S, Govaerts P. The phonological development in young hearing-impaired children with a cochlear implant. Proceedings of ELA Emergence of Language Abilities: Ontogeny and Phylogeny; 2005 Dec 8-10; Lyon, France.

14. Hargrove PM. Prosodic aspects of language impairment in children. Topics in Lang Disorders, 1997; 17: 76-85.

15. Devine AM, Stephen LD. Towards a new theory of Greek prosody: The suprasyllabic rules. TAPA, 1982; 112: 33-63.
16. Fernald A. Hearing, listening, and understanding: Auditory development in infancy. In: Bremmer G, Fogel A (eds.), Blackwell handbook of infant development. London: Blackwell Publishing, 2004; 35-70.

17. Katz GS, Cohn JF, Moore CA. A combination of vocal f0 dynamic and summary features discriminates between three pragmatic categories of infant-directed speech. Child Develop, 1996; 67: 205-17.

18. Kitamura C, Lam C. Age-specific preferences for infant-directed affective intent. Infancy, 2009; 14: 1-24.

19. Ishi CT, Ishiguro H, Hagita N. Evaluation of prosodic and voice quality features on automatic extraction of paralinguistic information. Proceedings of IEEE/RSJ Int. Conf. on Intelligent Robots and Systems; 2006 Oct 9-15; Beijing, China.

20. Papousek M, Bornstein MH, Nuzzo C, Papousek H, Symmes D. Infant responses to prototypical melodic contours in parental speech. Inf Behavior and Develop, 1990; 13: 539-45.

21. Nathani S, Oller DK. Prelinguistic vocal development in infants with typical hearing and infants with severe-to-profound hearing loss. Volta Rev, 2008; 108(2): 115-38.

22. Hide Q, Gillis S, Govaerts P. Suprasegmental aspects of prelexical speech in cochlear implanted children. Proceedings of the $8^{\text {th }}$ Annual Conference of the Int Speech Com Association; 2007 Aug 27-31; Antwerp, Belgium. Curran Associates, Inc.; 2008.

23. Ertmer D. Emergence of a vowel system in a young cochlear implant recipient. J Speech Lang Hear Res, 2001; 44(4): 803-13.

24. Lenden JM, Flipsen P. Prosody and voice characteristics of children with cochlear implants. J Commun Disord, 2007; 40(1): 66-81.

25. Oller DK, Lynch MP. Infant vocalizations and innovations in infraphonology: Toward a broader theory of development and disorders. In: Ferguson C, Menn L, Stoel-Gammon C (eds.), Phonological development: Models, research, implications. Parkton: York Press; 1992; 509-36.

26. Oller DK. The emergency of the speech capacity. New Jersey: Lawrence Erlbaum and Associates; 2000.

27. Koopmans-van Beinum FJ, van der Stelt JM. Early stages in the development of speech movements. In: Zetterstrom R (ed.), Precursors of early speech. New York: Stockton; 1986; 37-50.

28. Koopmans-van Beinum FJ, Clement CJ, van der DikkenbergPot I. Babbling and the lack of auditory speech perception: A matter of coordination? Develop Science, 2001; 4: 61-70. 
29. Schauwers K, Govaerts P, Gillis S. Co-occurrence patterns in the babbling of children with a cochlear implant. In: Davis B, Zajdo K (eds.), The syllable in speech production: Perspectives on the frame content theory. New York: Taylor and Francis; 2008; 187-204.

30. Miyamoto RT, Kirk KI, Robbins A, Todd S, Riley A. Speech perception and speech production skills of children with multichannel cochlear implants. Acta Oto-Laryngologica, 1996; 116(2): 240-43.

31. Tobey E, Geers A, Brenner C. Speech production results: Speech feature acquisition. The Volta Review, 1994; 96(5): 109-29.

32. Geers A, Nicholas J, Sedey A. Language skills of children with early cochlear implantation. Ear Hear, 2003; 24(1): 46S-58S.

33. Baudonck N, Dhooge I, D'haeseleer E, Van Lierde K. A comparison of the consonant production between Dutch children using CI and children using hearing aids. Int J Pediatr Otorhinolaryngol, 2010; 74: 416-21.

34. Löhle E, Frischmuth S, Holm M et al. Speech recognition, speech production and speech intelligibility in children with hearing aids versus implanted children. Int J Pediatr Otorhinolaryngol, 1999; 47(2): 165-69.

35. Van Lierde K, Vinck BM, Baudonck N, De vel E, Dhooge I. Comparison of the overall intelligibility, articulation, resonance, and voice characteristics between children using CI and those using bilateral hearing aids: A pilot study. Int J Audiol, 2005; 44: 452-65.

36. Kishon-Rabin L, Taitelbaum R, Muchnik C, Gehtler I, Kronnenberg J, Hildesheimer M. Development of speech perception and production in children with cochlear implants. Ann Otol Rhinol Laryngol, 2002; 111: 85-90.

37. Goffman L, Ertmer D, Erdle C. Changes in speech production in a child with a cochlear implant: Acoustic and kinematic evidence. J Speech Lang Hear Res, 2002; 45: 891-901.

38. Schramm B, Bohnert A, Keilmann A. The prelexical development in children implanted by 16 months compared with normal hearing children. Int J Pediatr Otorhinolaryngol, 2009; 73(12): 1673-81.

39. Schramm B, Bohnert A, Keilmann A. Auditory, speech and language development in young children with cochlear implants compared with children with normal hearing. Int J Pediatr Otorhinolaryngol, 2010; 74(7): 812-19.
40. Kishon-Rabin L, Taitelbaum R, Tobin Y, Hildesheimer M. The effect of partially restored hearing on speech production of postlingually deafened adults with multichannel cochlear implants. J Acoust Soc Am, 1999; 106(5): 2843-57.

41. Svirsky MA, Lane H, Perkell JS, Wozniak J. Effects of shortterm auditory deprivation on speech production in adult cochlear implant users. J Acoust Soc Am, 1992; 92(3): 1284-300.

42. Schauwers K, Gillis S, Daemers K, De Beukelaer C, Govaerts P. Cochlear Implantation between 5 and 20 months of age: The onset of babbling and the audiologic outcome. Otol Neurol, 2004; 25: 263-70.

43. Ertmer DJ, Kirk KI, Sehgal ST, Riley AI. A comparison of vowel production by children with multichannel cochlear implants or tactile aids: Perceptual evidence. Ear Hear, 1997; 18: 307-15.

44. Tobey EA, Angelette S, Murchison C. et al. Speech production performance in children with multichannel cochlear implants. Am J Otol, 1991; 12: 165-73.

45. Fernald A, Mazzie C. Prosody and focus in speech to infants and adults. Develop Psycho, 1991; 27(2): 209-21.

46. Papaeliou C, Minadakis G, Cavouras D. Acoustic patterns of infant vocalizations expressing emotions and communicative functions. J Speech Lang Hear Res, 2002; 45(2): 311-17.

47. Karousou A, Kati D, Stabouliadou Ch. Phonoprosodic shape of vocalizations during the transition from prelingual to lingual communication. Studies for the Greek Language, 2009; 29: 486-99.

48. Jusczyk PW. The Discovery of Spoken Language. Cambridge, Mass: The M.I.T. Press; 1997.

49. Schauwers K, Gillis S, Govaerts P. Babbling in early implanted CI children. Int Congress Series, 2004; 1273: 344-347.

50. Hayes B. Introductory Phonology. Wiley-Blackwell, 2009.

51. Oller DK, Eilers R. The role of audition in infant babbling. Child Develop, 1988; 59: 441-49.

52. Liwo H. Cochlear implant as an important factor of the development of prosodic features in prelingually deaf children under 2 years of age. J Hearing Science, 2011; 1(3): 73-75.

53. Boons T, Brokx J, Dhooge I et al. Predictors of spoken language development following pediatric cochlear implantation. Ear Hear, 2012; 33(5): 617-39. 